\title{
Taiwan's Banana-Producing Regions and the Japanese Market
}

\author{
KOSEKI Yoshiyuki \\ Graduate Student, Department of Geography, National Taiwan Normal University, \\ Taipei 106, Taiwan
}

\begin{abstract}
Taiwan's banana industry developed during the period of Japanese occupation, and Taiwan bananas monopolized the Japanese market until banana importation was liberalized in 1963. This paper examines the development of Taiwan's banana-producing regions by highlighting the relationship between Taiwan bananas and the Japanese market and the change in bananaproducing regions of Taiwan following the end of World War II. Before Japan colonized Taiwan in 1895, bananas were a subsistence crop mainly in northern Taiwan. However, during the colonial period, a commercial banana-producing region was formed in central Taiwan around Jiji. After World War II, while the colonial banana network was maintained, the production center moved southward to Chishan town, where bananas are mainly grown for the Japanese market. Both banana-producing regions are now facing such problems as the aging of farmers, shortage of successors, crop diseases, and typhoon damage. Besides, a price competition war in the Japanese market forces Taiwan growers to raise their competitiveness. By joining WTO, further reorganization of banana-producing regions is expected in Taiwan.
\end{abstract}

Key words: banana, banana-producing region, Taiwan, Japanese colonization, banana networks, World Trade Organization

\section{Introduction}

The banana has been a subsistence crop produced and consumed widely in the tropics and subtropics, while it is now massively consumed all over the world. Roughly one fifth of the world banana production is exported overseas, mainly to the advanced countries in the temperate regions. Transnational agribusiness firms, headquartered in North America and Europe, have played a major role in the commercial production and marketing of bananas from Central America, the Caribbean, and the Philippines. Some eighty percent of today's banana trade is under the control of such agribusiness firms as Del Monte, Dole, Chiquita, Fyffes, and Noboa (Atkins and Bowler 2001; Taylor 2003). Particularly American companies produced, transported, and imported bananas from Central America and the Caribbean, and bananas became an inevitable part of American diet during the twentieth century (Jenkins 2000).

Although scholarly attention is increasingly paid to the international food network and the role of agribusiness firms in supplying food, we need to pay more attention to the subsistence and local trade patterns of bananas. This is partly due to the fact that a vast majority of the banana are still produced and consumed locally, and also due to the assumption that local-historical inertia appears to produce varied production-trade patterns around the world. In order to obtain a balanced, comprehensive picture of bananas, case studies in various parts of the world need to be accumulated. This paper examines the case of Taiwan.

Although Taiwan accounts for a small percentage of world banana production and trade, it has maintained a close tie with the Japanese market. Taiwan's banana industry developed during the period of Japanese occupation, and Taiwan bananas monopolized the Japanese market until 1963 when banana importation was liberalized. Thus, Taiwan's banana industry needs to be scrutinized in the context of Japanese colonialism and the existence of a specific market. Thus, Taiwan, a minor producer of bananas, has played 
a specific role in the banana trade in East Asia. In the age of globalization with globalizing food networks, Taiwan's banana industry, highly dependent on the niche market of Japan, is now facing restructuring. Taiwan's case appears important in examining the global banana industry and banana networks.

The banana industry and banana-producing regions in Taiwan have not received much scholarly attention excepting several studies published in the 1970s. Most studies looked at the economic aspect of Taiwan bananas. Tachi (1973, 1974) discussed the development of Taiwan's banana industry in terms of regional characteristics of agriculture as well as the productivity and profitability of bananas. Chen (1972), who examined the international competitiveness of Taiwan bananas and the Japanese market, pointed out that while competition among worldwide banana exporting countries became increasingly acute, the international price of bananas declined and the production cost of Taiwan bananas increased, so the Japanese market might be replaced by the import from the Philippines and Latin America unless the quality of products was raised and the cost of production lowered. Ebato el al. (1973) considered that the planted area and the quantity of Taiwan bananas tended to decrease due to the conditions of the Japanese market, especially after the Japanese Government liberalized banana importation. On the other hand, Nakamura (1991) discussed Taiwan bananas botanically by analyzing introduced varieties of bananas and specifying their origins and dispersal in Taiwan.

These previous studies, however, do not focus on the way Taiwan's banana industry was formed, nor how Taiwan bananas were exported to Japan following the end of World War II. Since banana importation was liberalized in Japan, low-price bananas became increasingly imported from countries such as the Philippines where bananas are produced on a large scale at low cost by transnational agribusiness firms. This has reduced the market share of Taiwan bananas in Japan, weakening the traditional relationship between Taiwan and Japan. Consequently, researchers' interest in Taiwan bananas also decreased. Recent conditions of banana-producing regions in Taiwan remain unclear despite the fact that the restructuring of the banana industry has taken place and that the changing economy of bananas is important in examining Taiwan's agriculture in the age of globalization.

This paper starts from an overview of the historical development of Taiwan's banana industry since the period of Japanese colonization by looking at the relationship between the colony and suzerain. My focus is placed on the formation and change of banana-producing regions in Taiwan in response to the Japanese market. I will also focus on the system of banana marketing following the end of World War II by looking at the way the traditional system of production and distribution is maintained or revised. As Taiwan's banana-producing regions are dependent on the Japanese market, they need to be evaluated in the framework of global banana networks as well as the structure of domestic agriculture.

Taiwan has the traditional banana-producing region in the center of the island while the new producing-region is found in the southern part of the island. In central Taiwan, a questionnaire survey was conducted in August, 1997 and August, 1998 in Jiji town, Nantou County, which is called the "cradle of Taiwan bananas." A survey was also made in southern Taiwan in March, 1996 mainly in Shijou area of Chishan town, Kaohsiung County, which constitutes a new production center for the export to Japan. Aerial photographs combined with 1/25,000 topographic maps were analyzed to judge the land use. Inquiry was also made to the head office of Taiwan Provincial Fruit Marketing Cooperative (TPFMC) and its Taichung Branch. TPFMC is the only official agency that deals with banana exportation to Japan and domestic sales. Taiwan Fresh Banana Importers' Association, an import organization for marketing Taiwan bananas in Japan, was also studied.

\section{Colonial Origin of Commercial Banana Industry}

\section{Banana production under Japanese rule}

Although the banana was a subsistence crop in western and northern Taiwan, ${ }^{1}$ Japanese colonization, which began in 1895, promoted commercial production and marketing of bananas. 
With the effort of Miyakojima Kinjirou of Osaka Shousen Gaisha Keelung branch, Taiwan bananas were exported to Kobe, Japan for the first time (Wakatsuki 1976). This success caused a change of banana cultivation; by 1910 central Taiwan around Jiji had become the major banana-producing region for commercial purposes. ${ }^{2}$ The banana, a novelty for Japanese, became increasingly exported to Japan. ${ }^{3}$

In this period banana exportation became organized. An official organization was formed in central Taiwan to deal with banana exportation. To review this historical record, "Commemoration of the Tenth Anniversary of Taiwan Provincial Fruit Marketing Cooperative" provided valuable and reliable date. According to the record, Taiwan Viceroy Government promulgated the Law of Taiwan Important Products Association in 1914 (Table 1). The law helped to establish a trade association of farmers and brokers and to modify the traditional free transaction into bidding or auction. Consequently, Fruit Distributors' Association of Central Taiwan Area was established in 1915. However, 57 brokers participated in that association, excluding farmers. Worse still, under the collusion of those brokers, the wholesale price was fixed low, causing disadvantage to farmers. ${ }^{4}$

In 1924 Fruit Distributors' Association of Central Taiwan announced that banana farmers cultivating over three hectares on the hillside or one hectare on the plain would be admitted as members. The association changed the name to Taichung County Fruit Association the following year (Taiwan Provincial Fruit Marketing Cooperative 1985). This proved that during the Japanese occupation the production center of export bananas had shifted to central Taiwan. ${ }^{5}$

Following the development of banana production in central Taiwan, southern areas with warmer climate also went into a rush of banana cultivation from around 1920. According to the record of "Commemoration of the Tenth Anniversary of Taiwan Provincial Fruit Marketing Cooperative," exporters and farmers jointly established Kaohsiung County Fruit Association (equivalent to the present-day Kaohsiung Branch) in 1924, and Tainan County Fruit Association (equivalent to the present-day Chianan Branch) the next year.
Table 1. Development of commercial banana industry in Taiwan

1895 . Japan colonized Taiwan.

1903 . Taiwan bananas were exported to Kobe, Japan for the first time, and this success caused a commercial banana-producing region in central Taiwan around Jiji.

1914 . Taiwan Viceroy Government promulgated the Law of Taiwan Important Products Association.

1915 . The Fruit Distributors' Association of Central Taiwan Area was established.

1917 . Banana farmers established Banana Production and Trade Association, but the association of farmers fell apart in 1921.

1924 - Exporters and farmers jointly established the Kaohsiung County Fruit Association.

- Taiwan Seika Kabushiki Kaisha for promoting banana export to Japan was established.

1925 . The Fruit Distributors' Association of Central Taiwan changed the name to Taichung County Fruit Association.

- The Tainan County Fruit Association was established.

- Wholesalers' associations were organized in many parts of Japan.

1926 . Taiwan Federation of Fruit Associations started operations.

1945 . World War II came to an end.

1947 . Taiwan Provincial Fruit Marketing Cooperative United Company was established, and Kaohsiung County Fruit Association was renamed Kaohsiung Fruit Marketing Cooperative.

1950 . Taichung County Fruit Association changed its name to Taichung Fruit Marketing Cooperative.

1965 - A banana refrigeration warehouse was constructed at the port of Kaohsiung.

1974 . Kaohsiung became the only port of banana export, and southern areas, especially Chishan gradually became the center of banana production for Japan.

1975 . The central company and eight branches began to operate.

2002 . Taiwan joined World Trade Organization.

2005 . Executive Yuan, Council of Agriculture, permitted the entrance of civil exporters to the banana business.

Source: Taiwan Provincial Fruit Marketing Cooperative (1985), Wakatsuki (1976) and author's field survey. 
A new official organization called Taiwan Federation of Fruit Associations was formed and started operation in January 1926. This organization was in charge of all spheres of administration from gathering goods to delivery. Under the command of Taiwan Viceroy Government, Motoyama Bunpei, the governor of Taichung County, served concurrently as the chief officer of the Taiwan Federation of Fruit Associations (Taiwan Provincial Fruit Marketing Cooperative 1985).

Taiwan Seika Kabushiki Kaisha (Taiwan Seika K.K.) was established in December 1924 for promoting banana export to Japan. With the main office in Taichung, it capitalized 1,500,000 yen and Takada Motojirou was the president. Among the 30,000 stocks issued, Japanese importers held 6,000 shares, while Taiwanese (associations, exporters, and farmers) held 24,000 shares. As to the Taiwanese shareholders, 17,000 shares were issued to those in the Taichung area and 3,500 shares to Tainan and Kaohsiung areas respectively. As the exporters withdrew, their shares were transferred to three associations and the federation. These four organizations became the largest shareholders of Taiwan Seika K.K. (Taiwan Provincial Fruit Marketing Cooperative 1985).

Taiwan Seika K.K. worked to expand the consignment sale system and sales outlet. In order to assure the maximum transaction profit and the security of bill collecting, Japanese brokers and banana wholesalers organized wholesalers' associations in many parts of Japan in 1925. Taiwan Seika K.K. allowed these associations to run the wholesale market, which was the auction market (Taiwan Provincial Fruit Marketing Cooperative 1985). The banana price was decided at the wholesale market, which differed from the present system of wharfside price. ${ }^{6}$

Bananas were exported to the ports in Japan as well as those under Japanese occupation such as Pusan, Inchon, Seoul, Pyongyang, Sinuiju and Anton in Korea, Dalian, Shenyang and Harbin in Manchuria, Beijing, Tianjin, Shanghai, Nanjing, Fuzhiou and Xiamen in R.O.C, and even Hongkong. At these ports powerful local wholesalers were designated as the sales agents, and were forced to sell bananas at the designated price. It was called "designated agency system"
(Taiwan Provincial Fruit Marketing Cooperative 1985).

\section{Sustained banana networks}

During Japanese colonization, the distribution system including gathering, classifying, packing, and delivering had already been established to a certain extent. Following the end of World War II, Taiwan maintained its system of production and distribution, and kept exporting bananas to Japan. Bananas came mostly from central Taiwan. Until the Japanese Government liberalized the importation of bananas in 1963, Taiwan bananas monopolized the Japanese market.

As to the associations established during the colonial period, Taiwan Provincial Administration Agriculture and Forestry Department held a meeting of pan-provincial fruit cultivators and fresh fruit industry in September 1946 to proceed to reorganization. In 1947 Taiwan Provincial Fruit Marketing Cooperative United Company (equivalent to the present-day head office of TPFMC) was established, and Kaohsiung County Fruit Association was renamed Kaohsiung Fruit Marketing Cooperative. After some merger, Taichung County Fruit Association also changed its name to Taichung Fruit Marketing Cooperative in 1950. Before 1960 Taipei, Hsinchu, Taichung, and Kaohsiung counties all had their own cooperatives covering wider areas beyond county jurisdiction. Ilan County and Hualian County had their own cooperatives. ${ }^{7}$ Furthermore, a banana refrigeration warehouse ${ }^{8}$ was constructed at the port of Kaohsiung in July 1965.

Until 1973 Taiwan bananas were exported from either Keelung or Kaohsiung. ${ }^{9}$ Since the banana refrigeration warehouse was constructed, banana production in central Taiwan started to decline and overseas shipment from Keelung became difficult due to short supply. Kaohsiung became the only port of banana export after 1974. In April 1973 Mr. Chiang Ching-kuo, the chief officer of Executive Yuan, commanded these fruit cooperatives to merge. As of July 1975 the central company and eight branches (Taipei, Hsinchu, Taichung, Chianan, Kaohsiung, Pingtung, Tungtai, and Ilan) began to operate (Figure 1). Among these branches, Taichung, Chianan, Kaohsiung, Pingtung, and Tungtai dealt with ba- 


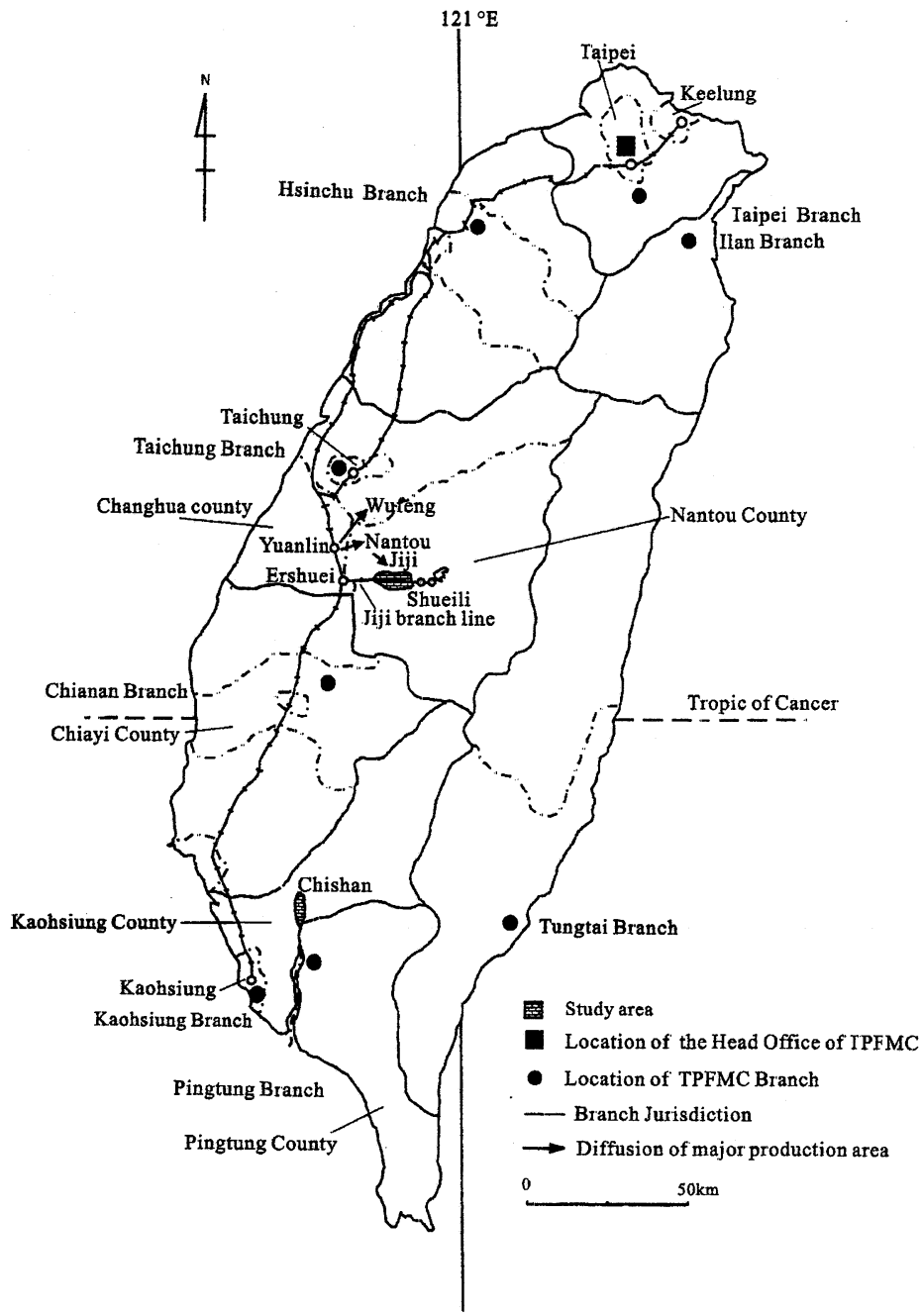

Figure 1. Productive region of Taiwan bananas.

nanas.

The longer banana grows from sprout to harvest, the better the quality will be. This is the reason why those cultivated on the hillside at higher elevation in central Taiwan grow better than those from the southern plains. In addition, Jiji basin in central Taiwan produces high quality bananas with adhesion and sweetness, due to a larger range of diurnal and annual temperatures. When exporting to Japan, no matter where the bananas come from, they have only one brand name as "Taiwan banana;" TPFMC being the only channel of banana export, it is hard to differentiate prices by production region. However, the situation differed in domestic sales. The bananas of higher quality from central Taiwan have higher domestic prices than those for export. $^{10}$

During the same period, the port of Kaohsiung became the only gate of banana export. Due to the reduced delivery cost, southern areas, especially Chishan town, Kaohsiung County became the center of banana production for the Japanese market. ${ }^{11}$ After World War II the former associations established during the colonial period were reorganized, but the banana network remained unchanged.

\section{Quantity of Taiwan banana exportation}

The 1996 production volume of Taiwan ba- 
nanas was 141 thousand tons (Taiwan Agricultural Yearbook), which accounted for some 0.25 percent of the global volume of 55,787 thousand tons (FAO Production Yearbook). In the same year the leading countries such as the Philippines and Ecuador produced 3,292 and 5,309 thousand tons respectively. Besides, the annual production volume in Taiwan decreased by 63 thousand tons in ten years. The annual quantity of exported Taiwan bananas ${ }^{12}$ in 1996 was about 4,316 thousand cartons (1 carton contains $12 \mathrm{~kg}$ ), or nearly 51.8 thousand tons (according to the exports record of TPFMC). In the same year, the global exportation of bananas was about 14,145 thousand tons (FAO Trade Yearbook), thus making Taiwan bananas an extremely trifling proportion of $0.37 \%$.

However, as far as the Japanese market is concerned, the significance of Taiwan is clearly understood. Japan's import of bananas in 1996 was 818,712 tons (Banana Imports Statistics), in which Taiwan bananas accounted for 50,616 tons, or $6.2 \%$. Furthermore, because Taiwan bananas are of superior quality compared to the import from the Philippines and Ecuador, its average annual wharfside price is 1.5 to 2 times higher than the latter two in recent years. This proves that Taiwan bananas have won fame in Japan. In the age of globalization the colonial banana network is still sustained, connecting Taiwanese banana producers and Japanese consumers.

\section{Traditional Center of Banana Produc- tion in Central Taiwan}

\section{The cradle of Taiwan bananas}

It was around 1910 when bananas were planted in central Taiwan for commercial purposes. Banana planting began in Yuanlin, and Wufeng, Nantou, and Jiji soon followed (Figure 1). Especially in Jiji where most of the flatland had already been planted to rice when the banana became a boom crop, the hillside had to be developed to plant bananas. Jiji became the center of commercial banana production known as the "cradle of Taiwan bananas."

There are reasons why Jiji became an important banana producing-region. The natural envi-
Table 2. Banana production in Nantou County (1994)

\begin{tabular}{lrr}
\hline \multicolumn{1}{c}{ Division } & Production (t) & Percentage (\%) \\
\hline Nantou City & 3,991 & 12.76 \\
Puli Town & 143 & 0.46 \\
Tsautuen Town & 1,200 & 3.83 \\
Jushan Town & 1,722 & 5.51 \\
Jiji Town & 5,424 & 17.34 \\
Mingjian Village & 1,100 & 3.51 \\
Lugu Village & 488 & 1.56 \\
Jungliau Village & 10,200 & 32.62 \\
Yuchr Village & 36 & 0.12 \\
Guoshing Village & 1,600 & 5.12 \\
Shueili Village & 5,343 & 17.09 \\
Shinyi Village & 15 & 0.05 \\
Renai Village & 10 & 0.03 \\
\hline \multicolumn{1}{c}{ Total } & 31,272 & 100.00 \\
\hline
\end{tabular}

Source: Nantou County Statistics.

ronmental factors such as the basin topography and the temperatures contributed to producing high quality bananas. The gravel soil performed better drainage, which was another advantage for fruit cultivation. Besides, bananas being an important commercial crop, cultivators were able to earn cash instantly. These factors explain why the earliest official organization was established in central Taiwan, and a systematic distribution system including gathering, classifying, packing, and delivering was soon built. More importantly, a branch line of the main north-south railway reached Jiji in 1921, completing the direct path to the port of Keelung and Kaohsiung. Although the Jiji branch line was originally built for constructing Daguan generating station in 1919, trains delivered Chinese cypress and bananas on their return trips. Following the completion of the generating station, the branch line continued to transport such commodities. In the peak harvesting season, trains full of bananas ran in the nighttime.

In Nantou County, Jungliau village, Jiji town, and Shueili village were most prosperous in banana production (Table 2). Jiji town and Shueili village together formed one producing region, whose total production exceeded that of Jungliau village. This is the reason why I chose Jiji for my investigation. Jiji town is located on the west foot of the Central Mountain. It takes two hours and 40 minutes from Taipei to Ershuei by train 


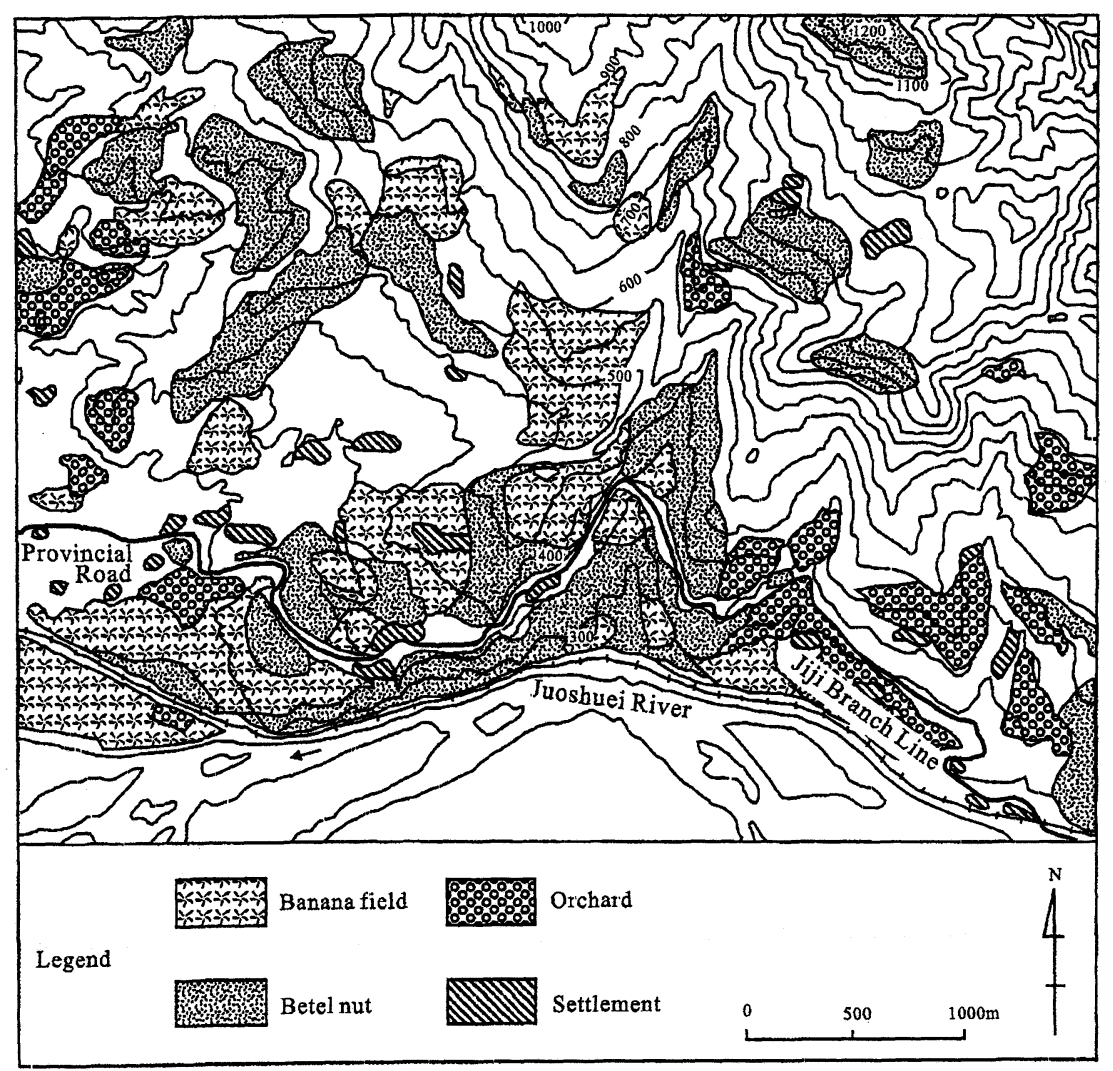

Figure 2. The land use from Jiji Town to Shueili Village (1998).

Source: Author's field survey and 1/25,000 topographical map of 1980.

(about $210 \mathrm{~km}$ ), then another 30 minutes from Ershuei to Jiji (about $20 \mathrm{~km}$ ). After about 15 minutes on the train for Jiji, passengers will see banana plantations on both sides of the railroad.

The eastern part of Jiji town is called Daping, adjoining Shueili village, and is especially prosperous in the banana cultivation. The Juoshuei River, the biggest river of Taiwan, runs through the south of Daping to the west, and Jiji branch railway line lies east and west in the north of the river (Figure 2). The area north of the Juoshuei River is mountainous exceeding $1,000 \mathrm{~m}$ of altitude. Agglomerated settlements spread along the provincial road at the altitude below $400 \mathrm{~m}$, yet a few settlements are found at the altitude of 800 to $900 \mathrm{~m}$.

In this area bananas are cultivated over the entire hillside even up to an altitude of $900 \mathrm{~m}$. Especially at high elevation, banana plantations can be seen over the ridges of the sunny side. On the other hand, in the eastern section ap- peared in Figure 2, many orchards of lichees, longans, and tangerines are observed. The lichee is especially popular in this area. Another interesting fact is the prevalence of betel nuts. In the aerial photograph taken in February 1979, banana trees are observed at an altitude of $1,000 \mathrm{~m}$ in desolate and scattered fields. This suggests that banana fields were taken over by orchards or betel nut groves between 1979 and 1998 .

\section{Banana cultivators}

I interviewed 33 banana-farming households in Jiji and the result is summarized in Table 3. These households belong to the jurisdiction of Jiji collection center, to which about 60 households supplied bananas.

Farm management of 33 households is examined by focusing on the income structure. Over sixty percent of them are part-time farmers. While the youngest is 38 years of age, over seventy percent were born during the period of 
Table 3. Banana cultivators in Jiji Town (1997-1998)

\begin{tabular}{|c|c|c|c|c|c|c|c|c|c|c|c|c|c|c|}
\hline \multirow[b]{2}{*}{ No. ${ }^{1)}$} & \multirow{2}{*}{ 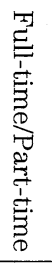 } & \multicolumn{6}{|c|}{ Labor structure ${ }^{2)}$} & \multirow[b]{2}{*}{ 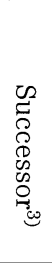 } & \multirow[b]{2}{*}{$\begin{array}{l}\text { Banana } \\
\text { specie }^{4)}\end{array}$} & \multicolumn{3}{|c|}{ Land area } & \multirow[b]{2}{*}{ } & \multirow[b]{2}{*}{ 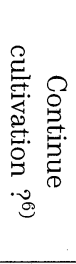 } \\
\hline & & $\begin{array}{l}\text { Owner } \\
\text { (age) }\end{array}$ & $\sum_{\infty}^{\infty}$ & 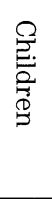 & 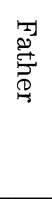 & 客 & 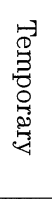 & & & $\begin{array}{c}\text { Banana } \\
\text { field } \\
\text { (ha) }\end{array}$ & Others (ha) & & & \\
\hline 1 & $\mathrm{~F}$ & $\mathrm{M}(65)$ & - & - & - & - & 一 & $x$ & H.j.C & 0.4 ha & Betel nut & $1.5 \mathrm{ha}$ & 1966 & 0 \\
\hline 2 & $\mathrm{P}$ & $M(55)$ & - & 0 & - & - & - & $\bigcirc$ & P.C & 0.7 ha & Betel nut & ? ha & 1967 & O \\
\hline 3 & $\mathrm{~F}$ & $\mathrm{M}(66)$ & - & - & 0 & - & - & 0 & H.j.C & $1.0 \mathrm{ha}$ & & & 1986 & 0 \\
\hline 4 & $\mathrm{P}$ & $\mathrm{M}(51)$ & - & - & - & - & - & O & H.j.C & $1.6 \mathrm{ha}$ & Pineapple & $0.3 \mathrm{ha}$ & 1965 & 0 \\
\hline 5 & $\mathrm{P}$ & $\mathrm{M}(58)$ & - & 0 & - & - & - & O & P.C & $1.2 \mathrm{ha}$ & Betel nut & ? ha & 1952 & 0 \\
\hline 6 & $\mathrm{~F}$ & $\mathrm{~F}(55)$ & - & - & - & - & - & $\times$ & T.C.2 & 0.7 ha & & & 1986 & O \\
\hline 7 & $\mathrm{P}$ & $M(56)$ & - & 0 & - & - & - & 0 & P.C & 0.8 ha & $\begin{array}{l}\text { Orange } \\
\text { Betel nut }\end{array}$ & $\begin{array}{l}\text { ? ha } \\
\text { ? ha }\end{array}$ & 1947 & 0 \\
\hline 8 & $\mathrm{P}$ & $\mathrm{M}(40)$ & - & - & - & - & - & 0 & P.C & 0.8 ha & Betel nut & ? ha & 1967 & 0 \\
\hline 9 & $\mathrm{P}$ & $\mathrm{M}(60)$ & - & - & - & - & - & 0 & P.C & $1.0 \mathrm{ha}$ & $\begin{array}{l}\text { Orange } \\
\text { Betel nut }\end{array}$ & $\begin{array}{l}\text { ? ha } \\
\text { ? ha }\end{array}$ & 1947 & 0 \\
\hline 10 & $\mathrm{~F}$ & $\mathrm{M}(70)$ & - & - & - & - & - & $x$ & H.j.C & 0.3 ha & Orange & 0.1 ha & 1941 & 0 \\
\hline 11 & $\mathrm{~F}$ & $\mathrm{M}(38)$ & - & - & - & - & - & 0 & H.j.C & 2.0 ha & $\begin{array}{l}\text { Lichee } \\
\text { Longan } \\
\text { Betel nut }\end{array}$ & $\begin{array}{l}0.7 \text { ha } \\
0.8 \text { ha } \\
2.0 \text { ha }\end{array}$ & 1986 & 0 \\
\hline 12 & $\mathrm{~F}$ & $\mathrm{M}(66)$ & - & - & - & - & - & 0 & T.C.1 & $1.3 \mathrm{ha}$ & & & 1979 & 0 \\
\hline 13 & $\mathrm{P}$ & $F(58)$ & - & 一 & - & - & - & 0 & T.C.1 & $0.3 \mathrm{ha}$ & & & 1957 & 0 \\
\hline 14 & $\mathrm{P}$ & $M(64)$ & 0 & - & - & - & - & 0 & H.j.C & 3.0 ha & $\begin{array}{l}\text { Tangerine } \\
\text { (Ponkan) }\end{array}$ & $1.0 \mathrm{ha}$ & 1956 & 0 \\
\hline 15 & $\mathrm{P}$ & $M(50)$ & - & 0 & 一 & - & - & 0 & P.C & 0.6 ha & $\begin{array}{l}\text { Orange } \\
\text { Betel nut }\end{array}$ & $\begin{array}{l}\text { ? ha } \\
\text { ? ha }\end{array}$ & 1967 & 0 \\
\hline 16 & $\mathrm{P}$ & $M(65)$ & - & - & - & - & - & 0 & H.j.C & 0.6 ha & & & 1959 & 0 \\
\hline 17 & $\mathrm{~F}$ & $M(73)$ & - & - & - & - & - & 0 & P.C & 0.7 ha & Orange & ? ha & 1937 & 0 \\
\hline 18 & $\mathrm{P}$ & $M(50)$ & - & - & 0 & 一 & - & $\bigcirc$ & H.j.C & $0.6 \mathrm{ha}$ & & & 1986 & 0 \\
\hline 19 & $\mathrm{P}$ & $M(50)$ & - & - & - & - & - & O & P.C & 0.5 ha & Betel nut & ? ha & 1957 & O \\
\hline 20 & $\mathrm{P}$ & $\mathrm{M}(63)$ & - & - & - & - & - & $\times$ & H.j.C & $0.5 \mathrm{ha}$ & & & 1952 & $x$ \\
\hline 21 & $\mathrm{P}$ & $\mathrm{M}(70)$ & - & - & - & - & - & O & P.C & $0.8 \mathrm{ha}$ & Mandarin orange & $1.0 \mathrm{ha}$ & 1963 & O \\
\hline 22 & $\mathrm{~F}$ & $\mathrm{M}(61)$ & - & - & 0 & - & 一 & 0 & P.C & $1.5 \mathrm{ha}$ & $\begin{array}{l}\text { Mandarin orange } \\
\text { Betel nut }\end{array}$ & $\begin{array}{l}1.0 \mathrm{ha} \\
1.0 \mathrm{ha}\end{array}$ & 1961 & O \\
\hline 23 & $\mathrm{P}$ & $\mathrm{M}(62)$ & - & - & - & - & - & 0 & P.C & $1.0 \mathrm{ha}$ & $\begin{array}{l}\text { Pineapple } \\
\text { Betel nut }\end{array}$ & $\begin{array}{l}0.5 \text { ha } \\
1.0 \text { ha }\end{array}$ & 1968 & 0 \\
\hline 24 & $\mathrm{~F}$ & $\mathrm{M}(69)$ & 0 & - & - & - & - & $x$ & P.C & $0.2 \mathrm{ha}$ & Rice nursery & ? ha & 1948 & $\bigcirc$ \\
\hline 25 & $\mathrm{~F}$ & $M(62)$ & - & - & - & - & - & $x$ & P.C & $0.5 \mathrm{ha}$ & Betel nut & $0.5 \mathrm{ha}$ & 1969 & 0 \\
\hline 26 & $\mathrm{P}$ & $\mathrm{M}(56)$ & ○ & - & - & - & 一 & 0 & P.C & $1.0 \mathrm{ha}$ & $\begin{array}{l}\text { Pear } \\
\text { Betel nut }\end{array}$ & $\begin{array}{l}\text { ? ha } \\
\text { ? ha }\end{array}$ & 1988 & O \\
\hline 27 & $\mathrm{P}$ & $\mathrm{M}(62)$ & - & - & 一 & - & - & O & P.C & $1.5 \mathrm{ha}$ & $\begin{array}{l}\text { Pear } \\
\text { Mandarin orange }\end{array}$ & $\begin{array}{l}0.5 \text { ha } \\
1.0 \text { ha }\end{array}$ & 1978 & 0 \\
\hline 28 & $\mathrm{P}$ & $\mathrm{M}(65)$ & O & - & - & - & - & 0 & P.C & $1.0 \mathrm{ha}$ & Lichee & $0.6 \mathrm{ha}$ & 1976 & 0 \\
\hline 29 & $\mathrm{P}$ & $\mathrm{M}(67)$ & - & - & - & - & - & $x$ & P.C & $0.8 \mathrm{ha}$ & Betel nut & $7.0 \mathrm{ha}$ & 1950 & $?$ \\
\hline 30 & $\mathrm{~F}$ & $M(60)$ & $\bigcirc$ & - & - & - & - & $\bigcirc$ & P.C & 0.7 ha & Mandarin orange & 0.6 ha & 1990 & 0 \\
\hline 31 & $\mathrm{P}$ & $M(45)$ & 0 & - & - & - & - & $\bigcirc$ & P.C & 0.8 ha & $\begin{array}{l}\text { Orange } \\
\text { Lichee }\end{array}$ & $\begin{array}{l}\text { ? ha } \\
\text { ? ha }\end{array}$ & 1948 & 0 \\
\hline 32 & $\mathrm{~F}$ & $M(61)$ & - & 0 & 0 & - & - & $x$ & P.C & $0.8 \mathrm{ha}$ & & & 1986 & 0 \\
\hline 33 & $\mathrm{P}$ & $F(39)$ & - & - & 0 & - & - & $?$ & P.C & $1.0 \mathrm{ha}$ & & & 1948 & 0 \\
\hline
\end{tabular}

1) No. 1-20 were investigated in 1997, and No. 21-33 were in 1998.

2) actual cultivator is indicated by $O$.

3) $\bigcirc$ : family with successor; $\times$ : family without successor; ?: unknown.

4) H.j.C: Hsien jen Chiao; P.C: Pei Chiao; T.C.1: Tai Chiao No.1; T.C.2: Tai Chiao No. 2.

5) ?: unknown.

6) $\bigcirc$ : continue cultivation; $X$ : discontinue cultivation; ?: unsure.

Source: Author's field survey. 
Table 4. Comparison of banana planting in Nantou County and Kaohsiung County (1997)

\begin{tabular}{lcccc}
\hline & Planting quantity & Planted area (ha) & $\begin{array}{c}\text { Average planting } \\
\text { per ha }\end{array}$ & Production (t) \\
\hline Nantou County & $3,065,000$ & 2,956 & 1,037 & 49,482 \\
Kaohsiung County & $4,137,000$ & 2,318 & 1,785 & 62,492 \\
\hline
\end{tabular}

Source: Taiwan Agricultural Yearbook.

Japanese occupation. Almost sixty percent of the farmers are over 60 years of age. Among fulltime farming families, only two (Nos. 6 and 11) are under 60 years of age. Local inhabitants born during the occupation are called "made-inJapan," while those who were born after World War II are called "made-in-Taiwan." To continue such a metaphor, over seventy percent of banana cultivators are "made-in-Japan."

Their cultivated areas range from 3 to 0.2 hectares, but most of them operate less than 1 hectare. According to the Basic Agricultural Statistics of R.O.C., the average cultivation area per household is 1.04 hectares. Such a family farm is typically operated by one or two household workers, usually older couple themselves.

Traditional varieties of Pei Chiao and Hsien jen Chiao are still popular. Taking advantage of the hillside topography, farmers could raise bananas directly with the original roots instead of replanting new seedlings.

Banana trees are easily hurt by typhoons. To reduce typhoon damage, 14 households diversify their cultivation by planting concurrently lichees or tangerines, more profitable crops. However, over forty percent of the households plant betel nuts. Some of these farmers treat betel nuts as an alternative crop to bananas, or plant them on the spare space in banana fields. Betel nut trees are easily planted and require minimum care, so that the production cost is almost zero. With the aging of farmers, there will be more and more households shifting from the banana to betel nuts. Betel nuts will eventually symbolize the abandonment of farming, the final stage of land use succession in the future. Betel nut trees grow slim and tall over the hillside, forming a weird landscape.

Farming households also face the problem of succession. Almost all the part-time farmers have successors, while most of the full-time farmers do not. In other words, younger people do not wish to be professional farmers, but would rather consider agriculture as a side job. Although most households continue to cultivate bananas, it is simply because the elders are used to the crop and have difficulty shifting to new crops, without a positive attitude toward banana cultivation.

\section{Banana cultivation on the hillside}

In the hillside cultivation in central Taiwan, the production per unit area is less than that in southern Taiwan. Compared with Kaohsiung County, the average production per hectare is 37.9 percent less than the former (Table 4). Therefore, although the total planted area is 27.5 percent more than that in Kaohsiung County, central Taiwan still produces 20.8 percent less than Kaohsiung. In addition, more and more farming households intend to quit banana cultivation due to heavy labor requirement and the aging of farmers. These are manifested in the increased number of betel nut trees.

The average annual temperature in central Taiwan is five degrees lower than that in southern Taiwan, thus making differences in the growing season. In central Taiwan, it takes fourteen months from seedling to harvest, while only twelve months are needed from replanting seedlings to harvesting in southern Taiwan. In Jiji, seedlings usually sprout from July to October, then after a ten-month growth, farmers start to cover bananas with plastic bags from May to August in the following year. After four months of covered growth, bananas are ready for harvest. The harvest season is from September through December.

Banana cultivators on the hillside are susceptible to the damage of Fusarium wilt, or Panama disease. Once a banana field is infected with the disease, the land can no longer be used for planting bananas unless farmers stop cultivating the banana and make use of the land as paddy field at least for two years in order to destroy or re- 
move all the virus. Hill topography here makes it difficult to change to paddy fields (Photo 1). ${ }^{13}$

\section{Domestic marketing}

At the collection center, bananas are sorted for export and for the domestic market. The banana export is regulated by TPFMC. The head office allots the quantity of banana export to each branch on the basis of production of each season while considering regional conditions.

When receiving the allotment, each branch demands its collection centers to gather products, considering the contracts with farmers who are willing to provide bananas for export. Assignment differs from one collection center to another. It also differs daily. When the assignment is satisfied, the surplus will be transferred to-

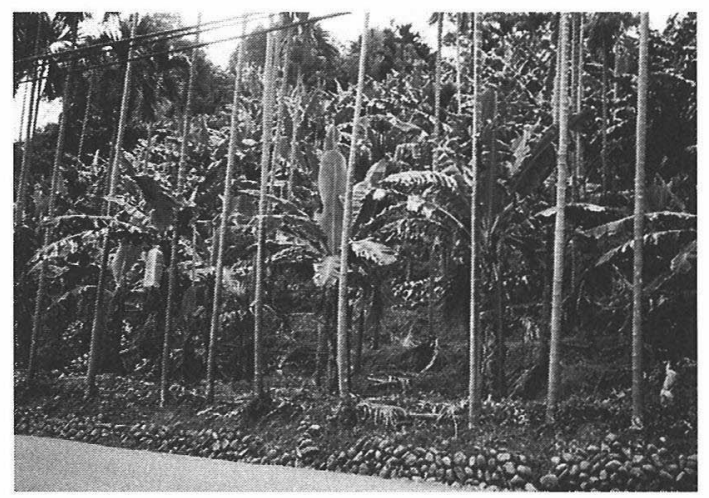

Photo 1. Banana fields on the hillside (12 Aug. 1998). ward the domestic market even though the banana meets export quality. However, if some collection center could not achieve the assignment, the surplus from other centers will make up for the shortage.

The chief of each collection center examines the bananas and divides them for export and for the domestic market. For the latter, bananas are classified into three ranks. "Extra Finest," which might even look better than the export banana, has the degree of maturity up to 85 percent. The second rank called "Finest" does not look as beautiful as Extra Finest, but the taste is still good. The third rank is called "Fine," inferior looking but good enough to eat.

When farmers cut the whole bunch of bananas for export from the neck of cluster, the "U-linecut" is applied with the entire stem removed after delivery to the collection center, while those for domestic market still have half of the stem connected (so called semi-cut). Such a difference is made to prevent local consumers from being confused or misled that domestic products might be inferior leftovers from export. The truth is that export bananas are classified through a certain specification, not by quality.

As a joint member of TPFMC, the farmer is obliged to provide all of his bananas to the contracted collection center. However, not all of them do so. In the domestic market, distributors can choose to deal with or without TPFMC (Figure 3 ).

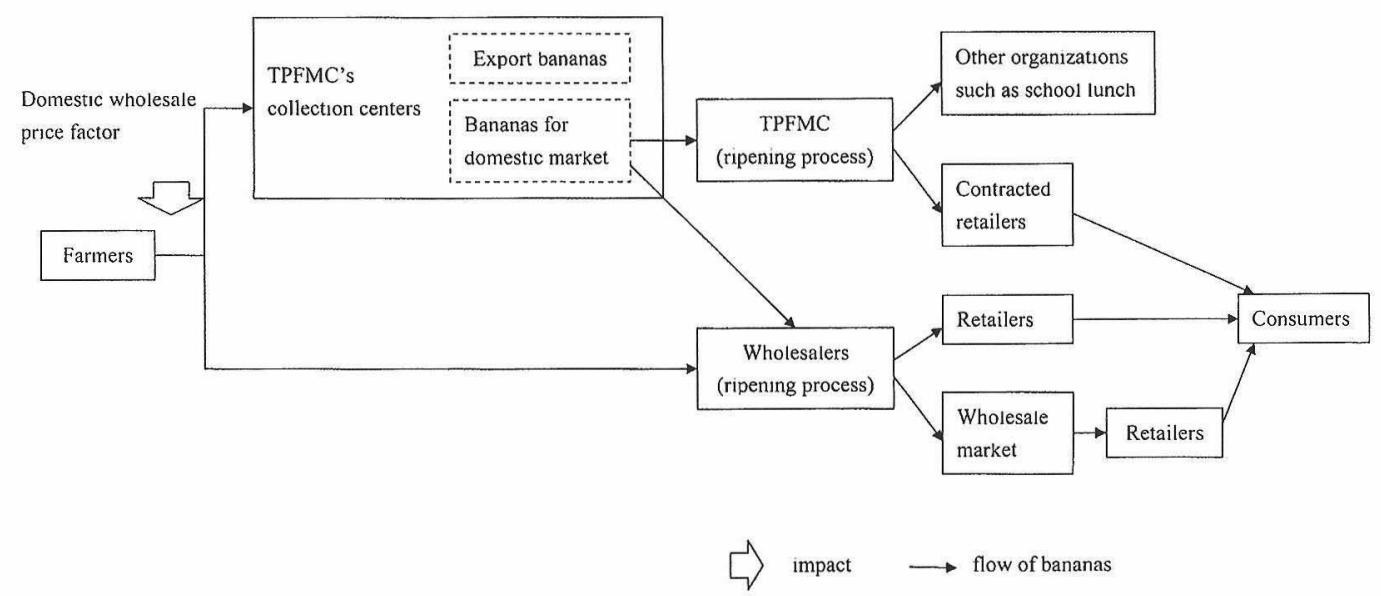

Figure 3. Collection and distribution of bananas in central Taiwan.

Note: As bananas need to ripen, after ripening, bananas are provided with wholesale market.

Source: Author's field survey. 
There are two distribution channels through TPFMC with the difference lying on where the ripening process takes place. One is that collection centers sell the product directly to the wholesaler, who will ripen the products on their own. The other channel is that the branches of TPFMC ripen bananas in its own factory before wholesaling to contracted retailers or other organizations. Among the five branches dealing with bananas, Taichung, Kaohsiung, Pingtung and Tungtai have ripening facilities.

Another distribution channel does not go through TPFMC. When domestic wholesale price is higher than what TPFMC offers, banana farmers might ignore their contracts with TPFMC and sell the product to domestic wholesalers. If a farmer cannot provide the contracted quantity due to such violation, TPFMC will charge him NT\$1 of each kilogram lacking, as a penalty. The penalty will be subtracted from the revenue-return to the farmer. Therefore, domestic wholesalers always offer prices at least twice the amount of the penalty in order to win the farmers' trust.

To sum up, the extraordinary land use of hillsides makes the Jiji region the leading banana production area of central Taiwan (Figure 4). Its high quality bananas raise domestic prices even higher than exporters' purchase price. However, due to hillside cultivation the average production per unit area is lower than that of southern Taiwan, and the landform makes it difficult to transform to paddy fields when banana trees are infected with Panama disease. In addition, new varieties resistant to Panama disease are not prevailing here. Hard and intensive farmwork makes these aging farmers abandon the banana cultivation one after another.

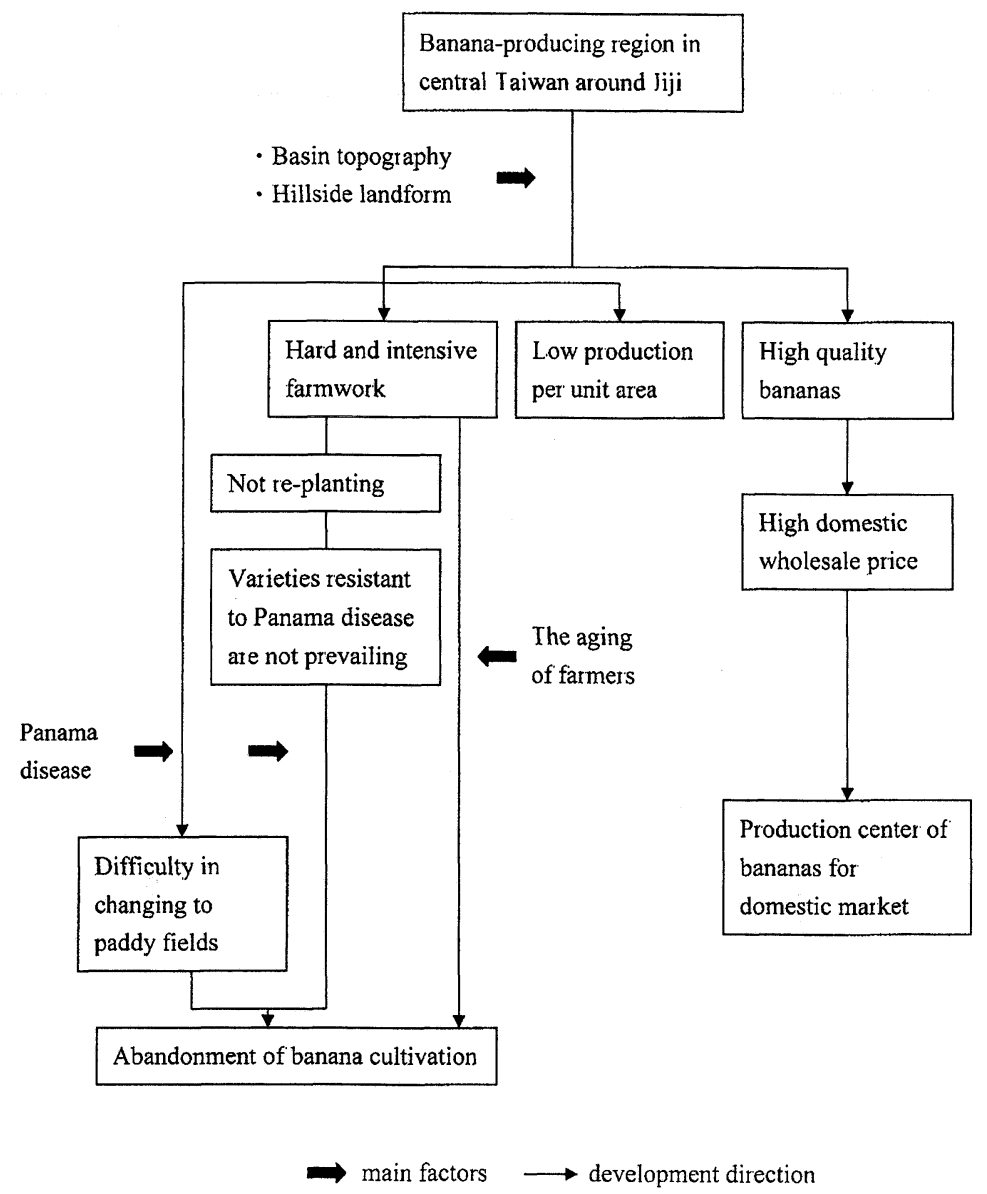

Figure 4. The structure of banana-producing region in central Taiwan. 


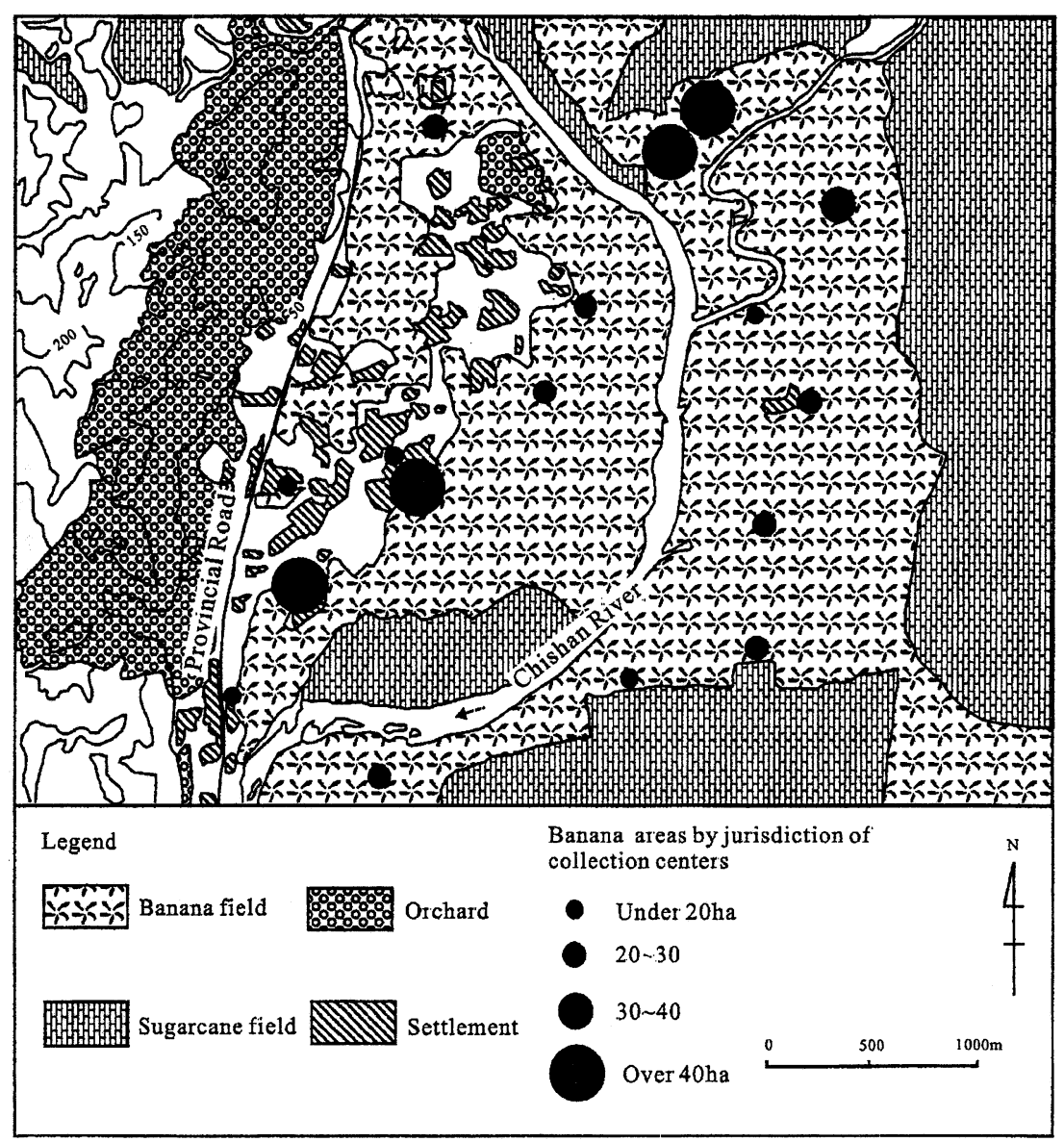

Figure 5. The land use of Shijou of Chishan Town (1996).

Source: Author's field survey and 1/25,000 topographical map of 1980.

\section{New Center of Banana Production in Southern Taiwan}

\section{Land use in Chishan}

Chishan, the present production center of exported bananas, is in Kaohsiung County of southern Taiwan (see Figure 1). It takes 4.5 hours by limited express train from Taipei to Kaohsiung City (about $360 \mathrm{~km}$ ), then an additional $70 \mathrm{~min}-$ utes by bus from downtown to Chishan (about $40 \mathrm{~km}$ ). There are about three buses every hour from Kaohsiung to Chishan. Riding the bus for 40 minutes from Kaohsiung, we will see banana fields spread out along the road.

The most prosperous region of banana cultivation in this town is the Shijou area. The Chis- han River winds through its central area to the south, and in the west runs the provincial road No. 21 (Figure 5). Across the road to the west is a gentle hill at a relative elevation of $150 \mathrm{~m}$, while to the east is the alluvial plain of the Chishan River at an altitude of only $40 \mathrm{~m}$. Settlements gather toward the eastern part of the provincial road, forming the agglomerated settlement.

The land use of the Shijou area can be divided into two patterns with the borderline of the provincial road (Figure 5). In the eastern plain, there are a few sugarcane fields along the river, while other sections are mostly banana plantations. Banana collection centers are located at regular intervals in the banana plantations. However, banana fields are not regularly developed, and the landownership boundaries are not well 
Table 5. Banana cultivators in Chishan Town (1996)

\begin{tabular}{|c|c|c|c|c|c|c|c|c|c|c|c|c|c|}
\hline \multirow[b]{2}{*}{ No. } & \multirow{2}{*}{ 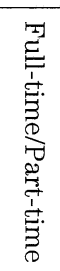 } & \multicolumn{6}{|c|}{ Labor structure $^{1)}$} & \multirow[b]{2}{*}{ 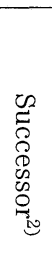 } & \multicolumn{3}{|c|}{ Land area } & \multirow[b]{2}{*}{ 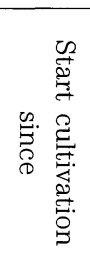 } & \multirow[b]{2}{*}{ 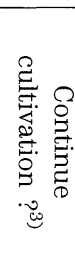 } \\
\hline & & $\begin{array}{c}\text { Owner } \\
\text { (age) }\end{array}$ & 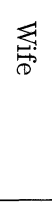 & 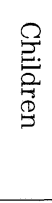 & 苞 & 空 & 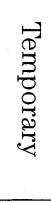 & & $\begin{array}{l}\text { Banana } \\
\text { field (ha) }\end{array}$ & Others & & & \\
\hline 1 & $\mathrm{P}$ & $\mathrm{M}(68)$ & 0 & - & - & - & - & $x$ & $2.0 \mathrm{ha}$ & Coconut & $2.0 \mathrm{ha}$ & 1961 & 0 \\
\hline 2 & $\mathrm{P}$ & $\mathrm{M}(55)$ & 0 & - & 0 & - & - & $x$ & $2.0 \mathrm{ha}$ & & & 1966 & 0 \\
\hline 3 & $\mathrm{~F}$ & $\mathrm{M}(64)$ & 0 & - & - & - & - & $x$ & $2.0 \mathrm{ha}$ & & & 1970 & 0 \\
\hline 4 & $\mathrm{P}$ & $M(43)$ & - & - & - & - & - & $x$ & $1.0 \mathrm{ha}$ & Papaya & $0.4 \mathrm{ha}$ & 1981 & 0 \\
\hline 5 & $\mathrm{P}$ & $M(55)$ & 0 & 0 & - & 0 & - & 0 & $0.9 \mathrm{ha}$ & & & 1966 & ? \\
\hline 6 & $\mathrm{P}$ & $M(48)$ & 0 & - & - & - & - & 0 & $1.0 \mathrm{ha}$ & & & 1976 & 0 \\
\hline 7 & $\mathrm{P}$ & $\mathrm{M}(51)$ & 0 & - & - & - & - & 0 & 3.0 ha & & & 1933 & 0 \\
\hline 8 & $\mathrm{~F}$ & $M(49)$ & 0 & 0 & - & - & - & $?$ & $3.5 \mathrm{ha}$ & $\begin{array}{l}\text { Coconut } \\
\text { Betel nut }\end{array}$ & $\begin{array}{l}2.0 \text { ha } \\
0.6 \text { ha }\end{array}$ & 1950 & O \\
\hline 9 & $\mathrm{P}$ & $\mathrm{M}(56)$ & 0 & - & - & - & - & 0 & $0.1 \mathrm{ha}$ & Lichee & $0.8 \mathrm{ha}$ & 1952 & 0 \\
\hline 10 & $\mathrm{~F}$ & $M(75)$ & 0 & 0 & - & - & - & 0 & $3.6 \mathrm{ha}$ & & & 1952 & 0 \\
\hline 11 & $\mathrm{~F}$ & $M(61)$ & 0 & - & - & 一 & - & 0 & $1.5 \mathrm{ha}$ & & & 1945 & 0 \\
\hline 12 & $\mathrm{P}$ & $\mathrm{M}(62)$ & - & - & - & - & - & ? & $0.8 \mathrm{ha}$ & & & 1968 & 0 \\
\hline 13 & $\mathrm{P}$ & $M(50)$ & 0 & - & - & - & - & $x$ & 0.6 ha & Betel nut & $0.5 \mathrm{ha}$ & 1975 & 0 \\
\hline 14 & $\mathrm{P}$ & $\mathrm{M}(40)$ & - & - & - & - & 0 & 0 & 20.0 ha & & & 1936 & 0 \\
\hline 15 & $\mathrm{~F}$ & $\mathrm{M}(68)$ & - & - & - & 一 & - & 0 & 0.7 ha & $\begin{array}{l}\text { Coconut } \\
\text { Lichee } \\
\text { Longan }\end{array}$ & $\begin{array}{l}0.5 \text { ha } \\
2.0 \text { ha } \\
3.0 \text { ha }\end{array}$ & 1956 & 0 \\
\hline 16 & $\mathrm{~F}$ & $\mathrm{M}(43)$ & - & - & - & - & O & $?$ & $3.5 \mathrm{ha}$ & $\begin{array}{l}\text { Coconut } \\
\text { Lichee }\end{array}$ & $\begin{array}{l}1.0 \mathrm{ha} \\
1.5 \mathrm{ha}\end{array}$ & 1946 & 0 \\
\hline
\end{tabular}

1) actual cultivator is indicated by $O$.

2) $\bigcirc$ : family with successor; $\times$ : family without successor; ?: unknown.

3) $\bigcirc$ : continue cultivation; ?: unsure.

Source: Author's field survey.

observed.

Sugarcane cultivation prospered during the period of Japanese occupation. Sugar products were delivered through the so-called Taiwan Sugar Railroad to the mouth of the Chishan River. But the railroad was abandoned after sugarcane cultivation declined. According to the aerial photograph taken in February 1976, most of the plains along the river were still sugarcane fields, a relic of the prosperous sugar period.

As to the western part, there are orchards all over the hill. Most of them are planted to lichees now, but in 1976 there were many fields of pineapples and bananas. Such gentle hillside topography is an advantage to fruit cultivation, while the lichee's better market price helps to expand the orchards.

\section{Banana cultivators}

I interviewed sixteen banana-farming households in Chishan, whose results are shown in Table 5. While their main crop was sugarcane during the Japanese occupation, they started to plant bananas following the end of World War II. In contrast to central Taiwan, Chishan is a new banana-producing region.

The income composition of these farming households reveals the farming economy. Over sixty percent are part-time farmers, the ratio being similar to that in Jiji of central Taiwan. Half of the full-time farmers plant coconuts or lichees concurrently with bananas in order to decrease the typhoon damage. As to their age, over sixty percent of farmers were older than 51 at the time of my inquiry in 1996, suggesting that they were born during the Japanese occupation. 
Those of 60 years and older accounted for forty percent. To use the aforementioned metaphor, sixty percent of the banana cultivators in Chishan are "made-in-Japan."

Each household owns a small plantation of two to three hectares excepting the farming household No. 14 that possesses the largest tract of land. The average plantation area of these minor cultivators is 1.74 hectares, being twice the size of Jiji's cultivators. Farming household No. 14 and No. 16 hire temporary farmhand, but the others mainly maintain their plantations by their own labor.

The lack of successors is a serious problem. Although many of the cultivators intended to continue planting banana themselves, half of them do not have any within the family to succeed farming or are not certain of it. This suggests that bananas are no longer attractive to the younger generation. ${ }^{14}$

\section{Banana cultivation on the plain}

Bananas are planted on the plain over southern Taiwan including Chishan. Such cultivation on flat land is easier than that on the hillside, especially when farmers replace the stools with new seedlings. When a cluster of bananas starts to form on a stool, there will be several new roots growing from the original one. After plucking bananas, farmers cut down the stool but leave the new roots until they become seedlings of about one meter high, then leave the finest seedling while digging others out. Usually they plant one new seedling between two original stools, and let the fallen trunks decomposed for two to three months right over where they were chopped. The replacement takes place from February through June. If a farmer plants a banana tree directly from the original root, such replacement can be skipped, yet there is still only one good shoot to be left.

Banana trees are eared six to eight months after replacement. The ears start to nutate within a week, and they will become the clusters afterward. Meanwhile, the trees themselves keep growing at this period. Farmers may have to use props $^{15}$ in the typhoon season from July to September or the stools are too high. Bamboo (Phyllostachys makinoi Hayata) is most commonly used for preservation props. Being heated in coal tar for a certain period of time, bamboo will be resistant to corruption for at least two to three years. Such a process cost NT $\$ 48$ for each pole.

When the bottom bunch comes out behind the buds, the calyxes darken and can be removed from the end of the fingers (banana fruits), farmers cover the cluster with P.E. bags. The bottom bunch together with the buds has to be removed because they do not have any commodity value but only consume much nutrition. The dark calyxes also need to be removed, for some vermin will oviposit on them. In Chishan, farmers usually do the covering between August and February. Bags can protect the fruits from sun, cold, and vermin, therefore a cluster can even grow heavier than $30 \mathrm{~kg}$. Low temperatures below 13 degrees cause bananas to catch cold, which prevents them from becoming completely yellow even after the ripening process; instead, green and crude parts are left on the fingers. This symptom is called Chin-Tan. Such low temperatures might happen irregularly from December through February in southern Taiwan, while in central Taiwan it might last to March. Although paper bags are more effective in avoiding ChinTan than P.E. bags, they cost almost twice the price of a P.E. bag (NT\$3.5) and are less convenient to handle. ${ }^{16}$ Four months after the covering procedure, bananas reach the 75 to 80 percent ripe stage and can be plucked. The harvest comes between December and June in Chishan, especially after March.

Intercropping is seldom seen in the banana field in this area, for it reduces the efficiency of banana cultivation. However, some farmers started to plant coconut palms as an intercrop in recent years. As the coconut palm needs ten years from planting to harvesting, those who intercrop coconut palms actually intend to make it take over bananas ten years later. In other words, coconut palms can be viewed as successors to bananas.

\section{The process of exporting to Japan}

Since bananas from southern Taiwan are mostly exported to Japan, the following paragraphs will focus on the process and route of exportation. Products are checked with certain standards after they are delivered to the collection center. The standard for inspection is pro- 


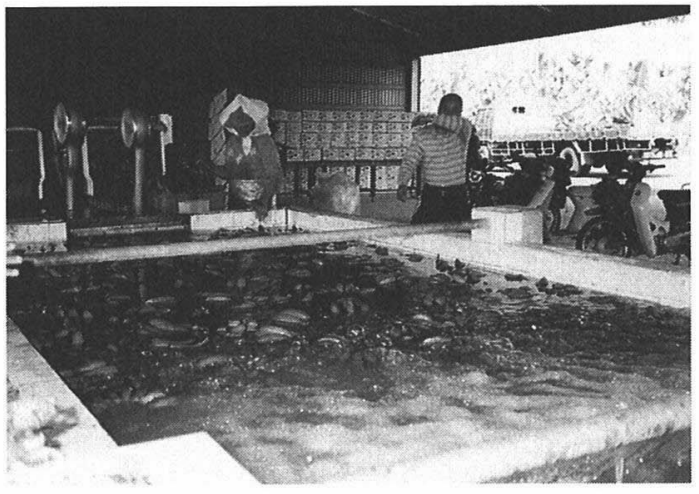

Photo 2. Disinfection and packing for export bananas to Japan in the collection center (6 Mar. 1996).

vided by Taiwan Fresh Banana Importers' Association. Those which pass the examination are to be given "U-line-cut" on the stem, thus to prevent stems from mildewing during the long journey to Japan.

The U-line-cut section is soaked in disinfectant to remove dust and worms like snails, then bananas are assorted in plastic containers (Photo 2). During this process, the weight of each bunch of bananas and the number of bunches to be contained in a carton $(12.5 \mathrm{~kg})$ are decided; the banana for export has to meet the restrictions specified by the Japanese market as well. In fact, the specification is set as $12 \mathrm{~kg}$ for one carton, but an extra of $0.5 \mathrm{~kg}$ is added as the commodity loses weight due to evaporation on their way from Kaohsiung to Japan. Although the capacity of a carton remains unchanged all the year round (one carton containing four to six bunches), the weight of a bunch differs from one season to another. For example, it may weigh 1.9 to $4.6 \mathrm{~kg}$ from March to June, and 2.1 to $4.6 \mathrm{~kg}$ in July. Each season has its detailed restrictions, and only qualified products can be packed into cartons. ${ }^{17}$ Besides, the weight of a bunch may possibly differ every year.

At the end of the packing process, qualification seals of registration mark are attached to each bunch. Those weighing over $3 \mathrm{~kg}$ have three seals attached to the middle and both ends, while those weighing below $3 \mathrm{~kg}$ have only two seals attached to both ends. When the packing process is finished, cartons of bananas are moved to the harbor (Photo 3), and stored temporarily

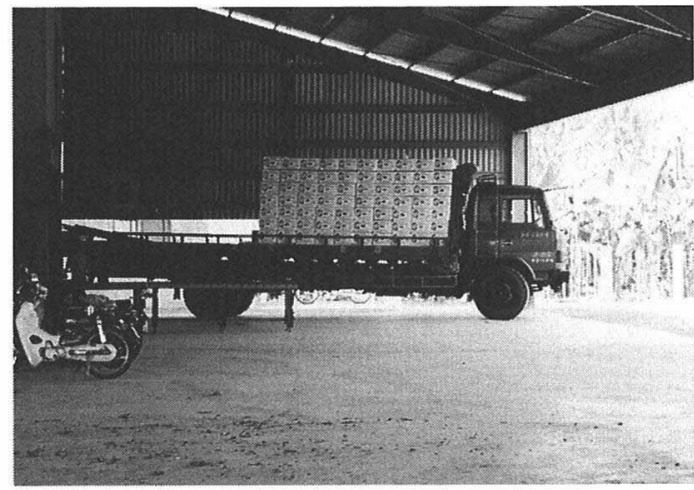

Photo 3. Export bananas for the port of Kaohsiung (6 Mar. 1996).

in the banana refrigeration warehouse. Its temperature is fixed to 14 to 15 degrees, but it is actually 20 to 25 degrees because of the frequent carry-in-and-out.

In this process, the ship is brought alongside the wharf in front of the warehouse. The hold is cleaned and precooled to 13.5 degrees. This is to prevent bananas from catching cold, while avoiding mildew or bacteria that become active in 15 degrees or warmer temperatures. ${ }^{18}$ When the loading is completed, the hatch is sealed. A banana transport ship can contain 60,000 to 130,000 cartons. To maintain the quality of bananas, the whole process from harvest to shipment must be completed in 36 hours.

There were nine ports in Japan that deal with the import of Taiwan banana in 1998; they are Otaru, Muroran, Tokyo, Kawasaki, Yokohama, Osaka, Kobe, Moji, and Hakata. After the departure, it takes about three days to the Kyushu area, four days to the Kansai area, five days to the Kanto area, and six days to Hokkaido. Not all the routes are direct. As Hokkaido has a smaller demand, the larger ship pulls into other ports such as Yokohama on their way to Hokkaido, while smaller ships may sail directly from Kaohsiung to the destination.

To sum up, bananas are planted on the plain by replacing the stools with new seedlings in Chishan. Taking advantage of the easy access to the port of Kaohsiung with low delivery cost, Chishan became the center of banana production to the Japanese market (Figure 6). However, the farmers face problems such as complicated specifications for export bananas and low rate of 


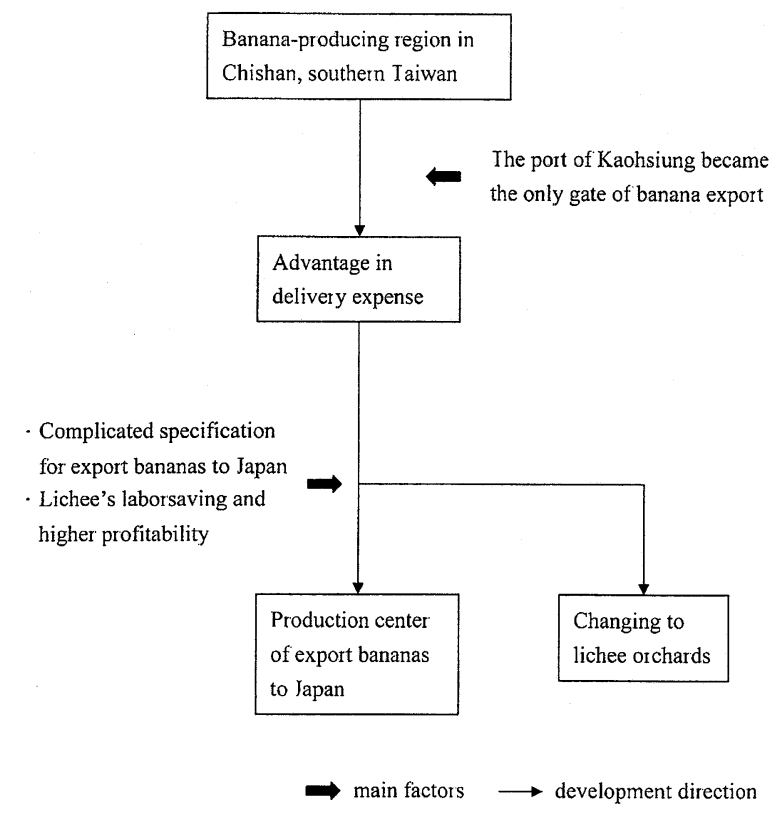

Figure 6. The structure of banana-producing region in southern Taiwan.

profit. Thus, banana production for the Japanese market is no longer attractive for many farmers in southern Taiwan.

\section{Taiwan's Banana Industry and the Global Banana Networks}

Taiwan's commercial banana industry, developed in close connection with the Japanese market, now has the following six characteristics. First, there are contracts between the banana farmers and TPFMC that guarantee the purchase price and product quantity. This was set in order to protect banana cultivators, encourage banana cultivation, and assure the exportation to Japan since 1977. The price is guaranteed during the peak of banana demand in Japan from February through July.

Second is the limited distribution channel. TPFMC actually monopolizes Taiwan's banana exportation. This system, intended to protect banana farmers' revenue from being sacrificed by some immoral distributors, and to enlarge the international competitiveness of Taiwan bananas was introduced on January 1, 1974.

Third, there is an agreement of revenue-return. Japanese importers who join Taiwan Fresh Banana Importers' Association (17 companies in
1998) must return half of their annual revenue to TPFMC, and the amount is paid back to the banana farmers in Taiwan. The system is operated as follows. There are three expenses for Japanese importers to pay when importing Taiwan bananas: the Cost, Insurance and Freight (C.I.F.) charge (including the shipping cost, insurance, guaranteed purchase price by Japanese Importers' Association, and TPFMC's expenditure), import duties, and the harbor miscellaneous expenses such as landing and unloading. The sum of these expenses is the original import cost of Taiwan bananas. Once the banana arrives at the Japanese harbor, the wharfside price is soon decided by the discussion of all affiliated importers. Wharfside price is what importers offer to fruit companies. Wharfside price subtracting the original import cost is the importers' revenue. Half of the yearly revenue of every importer is returned to TPFMC through Taiwan Fresh Banana Importers' Association. TPFMC gives the amount back to the producers. Such revenue-return system was introduced in 1980 and the Taiwan Government admits this agreement.

Forth, Taiwan bananas are highly evaluated in Japan. As Taiwan bananas taste much sweeter and more adhesive, accordingly they gain higher 


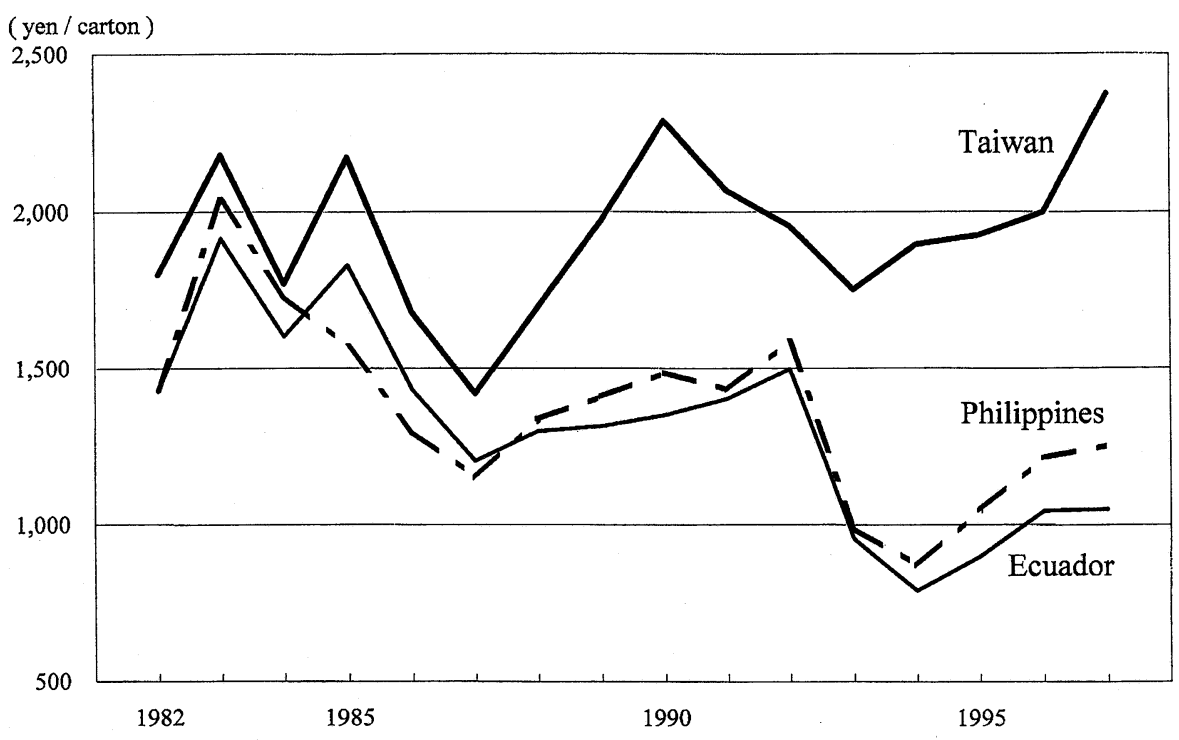

Figure 7. Japan wharfside price of imported bananas from different countries.

Source: Taiwan Fresh Banana Importers' Association and Fruit Importation Statistics.

wharfside prices than the product from other areas. While the wharfside price of Taiwan bananas tended to go up, Philippine and Ecuadorian bananas showed a general decline. The gap between Taiwan bananas and Philippine or Ecuadorian products has been enlarged (Figure 7). Consequently, in supermarkets or special fruit stores, the retail price is always higher than those from the Philippines and Ecuador.

Fifth, among major producers of bananas Taiwan is geographically the nearest to Japan. Bananas have better smell and taste as their maturity grows. However, the more matured the banana is, the sooner they ferment. When the delivery distance becomes longer, bananas need to be plucked at an earlier stage of maturity. Taiwan bananas are usually harvested at the 75 percent to 80 percent maturity, while bananas in the Philippines are harvested at the 70 percent maturity and those in Ecuador at the 65 percent maturity. A possibility of fermentation and further maturing during delivery still takes place. To prevent this, bananas for export are sealed by vacuum packing so as to restrict their breath. This is why Taiwan can provide the freshest and most highly matured bananas to Japan, the third major banana importing country in the world (1996 FAO Trade Yearbook).

Sixth, Taiwan has the best environment for ba- nana cultivation. Its subtropical climate, with lower average temperatures than the tropical Philippines or Ecuador, assures a longer growth period of bananas. The longer the bananas grow, the more sweetness and adhesion they gain. All of these make Taiwan bananas taste better.

Aforementioned characteristics of Taiwan bananas and their export industry appear to be unique in the global picture of banana networks. We need to evaluate Taiwan's case in the light of the global framework.

While the banana is widely grown and consumed as a subsistence crop in the tropics and subtropics, it is also a commercial crop in particular parts of the world to be produced on a large scale for a specific consumer market. Latin American countries such as Ecuador, Colombia, and Costa Rica produce bananas mainly for export, occupying a pivotal position in the global banana trade (Paggi and Spreen 2003). These countries together with Guatemala, Panama, Honduras and the Philippines account for about 80 percent of the world banana export.

In these countries transnational agribusiness firms have played an important role in producing, transporting, and marketing bananas to North American and European markets. The tropical lowland was developed for banana plantations by introduced capital and technology 
(Jones and Morrison 1952). The national economy became heavily dependent on the revenue from banana export (Paggi and Spreen 2003). American banana companies including United Fruit Company and Standard Fruit Company influenced the national economy and the government of Central American countries so that the term "banana republic" was coined (Karnes 1978; Jenkins 2000). This differs from Taiwan's case presented in this paper.

For both ends of production and consumption the banana is often a political and economic issue. Under the Lomé Convention, African, Caribbean, and Pacific (ACP) countries have been given preference in the EU banana market at the request of their former colonial powers, mainly Britain and France (Atkins and Bowler 2001; Coote 1992). This suggests that the former colonial tie is still maintained. Under the rule of WTO, however, the EU market is to be liberalized in 2006 (Josling and Taylor 2003). Transnational agribusiness firms, with the integrated system of banana production to distribution, appear to influence the global banana market by supplying low-price bananas.

Taiwan has maintained its banana network established during the colonial period, by receiving government protection after World War II. Due to the system of contract cultivation with guaranteed purchase price, the restricted distribution channel, and the revenue-return system honored by Japanese importers, together with its geographic proximity to Japan and high reputation among Japanese consumers, a unique connection has been maintained with the Japanese market. It is comparable to Latin American and Caribbean countries that have sustained ties with the EU and the United States.

Transnational agribusiness firms are vertically integrated, controlling production, ripening, and wholesaling in the entire chain. It is only at the retail stage that the bananas finally change hands (Atkins and Bowler 2001). Taiwan bananas, on the other hand, always change hands at the stage of collection and exportation in Taiwan and at the stage of importing, wholesaling, and retailing in Japan.

Commercial production of bananas developed in Taiwan and in such Latin American countries as Honduras, Colombia, and Costa Rica at almost the same period in history. However, the system of production and marketing in two banana-producing regions differed substantially. Transnational agribusiness firms led the entire venture in Latin America (Atkins and Bowler 2001; Brenes and Madrigal 2003), while in Taiwan the system of production and marketing was locally established for providing the Japanese market with bananas. Detailed comparison with Latin American cases will contribute to the further understanding of Taiwan's banana industry and banana-producing regions.

\section{Summary and Prospects}

While world-wide banana production and distribution is dominated by transnational agribusiness firms, Taiwan's banana industry sustains the colonial banana network, maintaining its longtime tie with the Japanese market. Japan is still the dominant export market for Taiwan bananas. However, due to declining production and exportation together with higher production costs, Taiwan bananas are now facing very severe competition in the export market. In the two major production centers of central and southern Taiwan, the banana farmers face the same problems, such as aging of farmers, shortage of successors, and the damage of Panama disease and typhoons. In central Taiwan, hillside banana fields are being abandoned, while in southern Taiwan, banana fields are changing to lichee orchards because of laborsaving and higher profitability. All of these factors combine to decrease the production of bananas in recent years.

Under such circumstances, the only way to reduce the total cost is to lower the delivery expense. In the Japanese market, which is the main overseas outlet for Taiwan bananas, price competition wars have taken place, forcing the Taiwan banana to raise its competitive edge. Consequently, bananas for export are provided mostly from southern Taiwan near the port of Kaohsiung; on the other hand, central Taiwan turns to provide bananas domestically to the Taipei metropolitan area, the biggest consuming center in Taiwan. The production area of export bananas, especially to Japan, has moved southward.

However, even in Chishan, the production cen- 
ter of export bananas to Japan, the situation has changed. Among sixteen banana cultivators I interviewed, nine started to provide part of their product domestically, and more cultivators are going to follow. This may be partly because of the complicated specifications for export bananas. Bananas for the domestic market, being classified into three ranks, are much easier for cultivators. In addition, domestic wholesalers offer higher prices than TPFMC. There is less and less advantage in producing bananas for export.

The traditional distribution system based on the singled-channel of exportation is now challenged as it is considered incapable of dealing with today's competitive situation. Executive Yuan, Council of Agriculture, permitted the entrance of civil exporters to the banana business as of January 1, 2005. It is intended to expand the banana export by raising competitiveness in the Japanese market.

To sum up, Taiwan's banana industry is going to enhance its domestic-market orientation instead of exportation because of the following factors: decreasing quantity of product, higher domestic prices, and lack of regulations and specification. Meanwhile, the entrance of civil exporters is permitted by Council of Agriculture to enlarge the exportation and to gain competitiveness in the Japanese market. By joining WTO, Taiwan Government will eventually permit the import of foreign bananas of lower prices. This will certainly bring about further reorganization of banana-producing regions in Taiwan as the banana farmers have to face competition in the domestic market as well. Producers of other tropical fruits such as mangos will also have to cope with the international competition.

\section{Acknowledgments}

This paper is partly based on my master's thesis submitted to Yokohama National University. I would like to express my sincere gratitude to Professor Yagasaki Noritaka, now at Tokyo Gakugei University. Professor Yaji Masataka of Yokohama National University, Professor Nakamura Kazuo of Komazawa University, and Professor Yamano Akio of Aichi Gakuin University also helped me complete my study. Thanks also go to Professor Chen Hsien-ming of National Taiwan Normal University, Professor Kuo Wan-shun of Chinese Medical
College, the staffs of TPFMC, Mr. Kobayashi Kazuhiko of Taiwan Fresh Banana Importers' Association, Mr. Goto Osamu, Ms. Lai Yu-fang, and Ms. Liu Ying-hui. I owe them great thanks.

(Received 9 March 2005)

(Accepted 20 February 2006)

\section{Notes}

1. Although two varieties of bananas, Musa Formosana and Musa Insularimontana, are native to Taiwan, neither of them is representative of Taiwan bananas now. Pei Chiao, presently a dominant variety, was introduced from Mainland China by the immigrants from Fujian province to northern Taiwan around 1730 (Tsai 1997). Pei Chiao was planted for subsistence all over western Taiwan. Northern Taiwan, however, eventually proved to be less suitable for such a tropical fruit due to low temperatures during the winter. Before Japan colonized Taiwan in 1895, Pei Chiao remained a subsistence crop mainly in northern Taiwan.

2. Based on the interview with Mr. Shi Qiu-ke, the director of TPFMC.

3. There was a folk song about banana sacrifice sale: "Born in Taiwan Taichung, down on Ali mountain foot. Pretty and mature as country maid. Pluck a bunch or two, put in round Chinese basket to leave Ali mountain, then packed in swinging train all the way to Keelung harbor." The folk song indicates that Taiwan bananas were gathered in central Taiwan, then delivered to the port of Keelung. Banana sacrifice sale began in 1904 at Moji of northern Kyushu. During that time when rough bamboo baskets of $48 \mathrm{~kg}$ capacity were used to pack bananas for a long-distance delivery, bananas were easily hurt, and those which were flawed were discounted and sold right at the port of Moji. Therefore, Moji is called "the birthplace of banana sacrifice sale."

4. According to the "Commemoration of the Tenth Anniversary of Taiwan Provincial Fruit Marketing Cooperative," banana farmers established their association called Banana Production and Trade Association against the brokers' association in 1917. This association intended to carry out the joint delivery to Japan, which caused conflict between the two associations. However, during World War I, all the ships were under requisition and the association of farmers fell apart in 1921 as the delivery system was halted.

5. Another factor contributed to the location shift of banana production. According to an interview 
with Taiwan Banana Research Institute, a mutation of Pei Chiao was found in Nantou County around 1912. The new variety was about $60 \mathrm{~cm}$ taller than the original, and had resistance to Banana bunchy top virus. It was considered "a gift from God," so was named Hsien jen Chiao, meaning "immortal banana." Thus, Pei Chiao and Hsien jen Chiao became the main banana varieties in Taiwan.

6. According to Mr. Huang Chao-yang, the head of the Instruction Team of the head office of TPFMC, auction market took 10 percent of the auction price as commission, from which 70 percent would be shared with the wholesaler's association, and the rest went to Taiwan Seika K.K. Among the association's share, three-sevenths was used to run the association business, and the rest was divided into exact halves for the highest bidder and the association members. As to the part of Taiwan Seika K.K., one-third of its commission was used to grant to the producers, and the rest was used for ordinary expenses.

7. Based on the interview with Mr. Huang Chaoyang, the head of the Instruction Team of the head office of TPFMC.

8. It was the largest facility in Asia, with a two-story warehouse having 7,800 square meters, costing NT\$41,000,000.

9. Based on the interview with Mr. Huang Chaoyang, the head of the Instruction Team of the head office of TPFMC.

10. According to Mr. Huang Chao-yang, the head of the Instruction Team of the head office of TPFMC, their banana transaction price is about NT\$13 to 18 per kilogram, while domestic wholesale brokers purchase bananas from central Taiwan at a price around NT $\$ 20$ to 30 per kilogram at the time of my investigation in 1997.

11. According to TPFMC Taichung Branch's shipment record, the delivery cost for each $12.5 \mathrm{~kg}$ from Jiji to Kaohsiung harbor was NT\$10.6 at the time of my investigation in 1998.

12. TPFMC has unified Taiwan bananas as the only brand name, whether the products come from central or southern area. But in the Philippines and Ecuador, individual agribusiness firms use their own brand names.

13. Although Taiwan Banana Research Institute developed banana varieties resistant to Panama disease such as Tai Chiao No. 1, it is not popular in this area. Taiwan Banana Research Institute was established in July, 1970 in order to raise the harvest, to reduce the production cost, and to improve the quality after the appeal made by For- eign Exchange Executive Council during the golden period of Taiwan bananas in the late 1960s. This corporate body was capitalized with NT $\$ 7,500,000$ from Banana Quality Improvement Foundation, NT $\$ 1,000,000$ from Joint Commission on Rural Reconstruction, and NT $\$ 1,500,000$ from TPFMC.

14. In the past, bananas were the most profitable crop in Taiwan, and banana farmers were consequently considered rich. Because banana sap blackens clothes and is hard to be washed off, it was even said that those who dressed dirty with dark spots on the clothes were very welcomed in bars, for they looked wealthy. The more they wore dirty clothes, more women adored them.

15. These props are about $3.6 \mathrm{~m}$ in length. One of the ends is buried $60 \mathrm{~cm}$ deep in the soil. A prop is often tightened with a banana tree at three places: $60 \mathrm{~cm}$ high from the ground, another $60 \mathrm{~cm}$ high, and the neck of the cluster.

16. According to Mr. Huang En-hsiung, the chief of $\mathrm{R}$ $\& \mathrm{D}$ section of planning department in the head office of TPFMC, Latin America was already known to use clear plastic bags in 1966. After many experiments proceeded by $\mathrm{Mr}$. Chu Chingkuo in Chiayi Agricultural Research Institute, Chu finally came to the conclusion in 1971 that the blue plastic bags used today are the best ones for sun block and keeping temperature at night. Therefore, blue plastic bags still prevail.

17. Under such severe circumstances, Taiwan Fresh Banana Importers' Association suggests the necessity of unifying the specification of Taiwan bananas in order to raise its competitiveness, thus possibly helping Taiwan to resolve the problem of losing market share after the liberalization of banana importation.

18. All the transport ships are equipped with air-conditioners, while ventilation ships were used until 1951.

\section{References}

Atkins, P., and Bowler, I. 2001. Food in society: Economy, culture, geography. London: Arnold.

Brenes, E., and Madrigal, K. 2003. Banana trade in Latin America. In Banana wars: The anatomy of a trade dispute, ed. T. Josling and T. Taylor, 97-122. Cambridge: CABI Publishing.

Chen, R. 1972. Taiwan banana no keizai kouzou. Journal of Agriculture and Economics 38: 53-57. (J)

Coote, B. 1992. The trade trap: Poverty and the global commodity markets. Oxford: Oxfam.

Ebato, A., Kosaka, N., and Akasaka, N. 1973. Regional 
changes in Taiwan's agriculture and its regions in the recent years. Memoirs of the Institute of Cultural Sciences, Meiji University 11: 1-73. (JE)

Jenkins, V. S. 2000. Bananas: An American history. Washington, D.C.: Smithsonian Institution Press.

Jones, C. F., and Morrison, P. C. 1952. Evolution of the banana industry of Costa Rica. Economic Geography 28: 1-19.

Josling, T., and Taylor, T. 2003. Conclusion. In Banana wars: The anatomy of a trade dispute, ed. T. Josling and T. Taylor, 195-203. Cambridge: CABI Publishing.

Karnes, T. L. 1978. Tropical enterprise: Standard fruit and steamship company in Latin America. Baton Rouge: Louisiana State University Press.

Nakamura, T. 1991. Banana gaku nyumon. Tokyo: Maruzen Library. (J)

Paggi, M., and Spreen, T. 2003. Overview of the world banana market. In Banana wars: The anatomy of a trade dispute, ed. T. Josling and T. Taylor, 7-16. Cambridge: CABI Publishing.

Tachi, S. 1973. Taiwan ni okeru banana seisan no hat- ten katei (1). Journal of Rural Community Studies 36: 44-73. (J)

Tachi, S. 1974. Taiwan ni okeru banana seisan no hatten katei (2). Journal of Rural Community Studies 38: 31-61. (J)

Taiwan Provincial Fruit Marketing Cooperative. 1985. Commemoration of the tenth anniversary of Taiwan Provincial Fruit Marketing Cooperative. Taipei: Taiwan Provincial Fruit Marketing Cooperative. (C)

Taylor, T. 2003. Evolution of the banana multinationals. In Banana wars: The anatomy of a trade dispute, ed. T. Josling and T. Taylor, 67-96. Cambridge: CABI Publishing.

Tsai, P. 1997. From introduction to prosperity: Brief history of Taiwan banana cultivation. Historical Monthly 119: 34-44. (C)

Wakatsuki, Y. 1976. Banana no keizai gaku. Tokyo: Tamagawa University Publish. (J)

$(J)$ : written in Japanese

(JE): written in Japanese with English abstract

(C): written in Chinese 